\title{
Influence of Date of Planting, Nitrogen Application and Planting Geometries on Growth, Biomass Yield and Essential Yield of Palmarosa (Cymbopogon martinii Roxb. Wats) under Sub-Mountainous Region of Punjab
}

\author{
Sukhjit Kaur ${ }^{1}$, Mandeep Kaur Saini ${ }^{1 *}$ and Deepinder Kaur Bakhshi ${ }^{2}$ \\ ${ }^{1}$ PAU Regional Research Station, Gurdaspur (Punjab) - 143521, India \\ ${ }^{2}$ Punjab State Council for Science and Technology, Chandigarh-160019, India \\ *Corresponding author
}

\section{A B S T R A C T}

\section{Keywords}

Biomass yield, Date of planting,

Essential oil,

Nitrogen,

Palmarosa

\section{Article Info}

Accepted:

12 October 2019

Available Online:

10 November 2019
A field experiment was conducted at Punjab Agricultural University, Regional Research Station, Gurdaspur during two year crop cycles of 2013-14 and 2014-15 to find out the effect of date of planting, nitrogen application and planting geometries on the biomass yield and essential oil yield of palmarosa under sub-mountainous region of Punjab. The experiment was laid out in split-split plot design having three replications with three planting dates of palmarosa viz. April 25, May 10 \&May 25, three nitrogen levels $\left(50,100\right.$ and $\left.150 \mathrm{~kg} \mathrm{ha}^{-1}\right)$ in sub-plots and three planting geometries $(60 \mathrm{~cm} \times 30 \mathrm{~cm}, 60 \mathrm{~cm} \times 45 \mathrm{~cm}$ and $60 \mathrm{~cm} \times 60 \mathrm{~cm})$ in sub-sub plots during two year crop cycles. The highest biomass yield and essential oil yield were recorded in April 25 which obtained higher biomass yield and essential oil yield than May 10 and May 25 at each harvest during both the years of crop cycles. Also, higher biomass yield and essential oil yield were recorded in crop raised with $150 \mathrm{~kg} \mathrm{~N}^{-1}$ which was statistically at par with $100 \mathrm{~kg} \mathrm{~N} \mathrm{ha}^{-1}$ during each harvest of palmarosa. Among planting geometries, the highest biomass yield and essential oil yield were observed in planting geometries $60 \mathrm{~cm} \times 30 \mathrm{~cm}$, which were significantly superior to $60 \mathrm{~cm} \times 60 \mathrm{~cm}$ and $60 \mathrm{~cm} \times 45 \mathrm{~cm}$. Further, date of planting, nitrogen application and planting geometries did not cause significant variation in the oil concentration.

\section{Introduction}

Palmarosa (Cymbopogon martinii Roxb. wats) is tall, multi-cut, perennial aromatic grass belonging to family Poaceae. It is having fibrous shallow roots, erect culms over 1.5 -
$2.5 \mathrm{~m}$ tall with swollen nodes. The leaf sheath is glabrous, membranous ligule with flat and linear leaf blades. Inflorescence is large compound panicle. Mature seeds of palmarosa are brown, fine, hairy and easily disposed by air. The grass is also referred as "Rosha grass" 
which yields an essential oil on hydrodistillation of its biomass. This essential oil is present in all parts of palmarosa viz., inflorescence, leaves and stem of which the inflorescence contains the major portion. Palmarosa oil is the best natural source of perfumery chemicals like geraniol (75\%), geraniol acetate (20\%), concentrations of linalool (2\%), $\alpha$-terpineol, geranyl isobutyrate, etc. (Rao et al., 2005). Palmarosa is considered to be a native of India and grows wild in Madhya Pradesh, Karnatka, Uttar Pradesh, Bihar and Odisha. India ranks first among the palmarosa oil producing countries and is the major supplier to the world market. In India about 15 metric tonnes of palmarosa oil is produced annually both from cultivated and natural resources (Gingade et al., 2014). Essential oil of palmarosa is pale yellow in colour, possessing a pleasant odour and is valued highly in cosmetics, perfumery industry (Mallavarapu et al., 1998) and pharmaceutical products (Akhila, 2009). This oil possesses some of the important properties such as insect repellent (Das and Ansari, 2002) and action against various bacteria (Lodhia et al., 2009), fungi (Bard et al., 1988) and micro-organism (Rao et al., 2009). Traditionally, palmarosa oil was used in treatment of skin infection like acne and also to stimulate cell generation, prevents ugly scarring in healing wounds, as a remedy for lumbago, stiff joints and bilious complaints. It is also used in aromatherapy (Fatima et al., 2002). There are many factors that affect agronomic characteristics, biomass and essential oil yield of aromatic plants (Khazaie et al., 2007). Date of planting, nitrogen requirement and planting geometries are amongst the most limiting factors for crop yield of environmentally sound agriculture. Plant age and crop density are among the most important factors that influence the yield of aromatic plants (Marotti et al., 1994). The influence of spacing on agronomic characteristics, biomass, essential oil content and essential oil yield were also reported by Zewdinesh and Beeemnet, 2012 in palmarosa. Being a member of poaceae family, palmarosa crop responded well to nitrogenous fertilizers, which affect the essential oils yield of palmarosa by the increase of the production of total biomass per unit of area (Sarma et al., 1977). Plant spacings, both row to row and plant to plant, play a significant role in the production of aromatic grasses. It is governed by various edapho-climatic factors to a large extent leading to varying results at different locations (Singh et al., 2000). In the paucity of information on its cultivation under Punjab conditions, the present investigation was undertaken to study the effect of date of planting, nitrogen and planting geometries on growth, biomass and essential oil yield of palmarosa (Cymbopogon martini Roxb. wats.) under sub-mountainous region of Punjab.

\section{Materials and Methods}

Two field experiments each for two years were conducted during 2013-15 and 20142016 at Punjab Agricultural University Regional Research Station, Gurdaspur in submountainous region of Punjab which is situated between $32^{\circ} 3^{\prime} \mathrm{N}$ latitude, $75^{\circ} 22^{\prime} \mathrm{E}$ longitude and has an altitude of about $257 \mathrm{~m}$ from mean sea level. The soil of experimental field was clayey loam in texture, medium in organic carbon $(0.49 \%)$, medium in available $\mathrm{P}_{2} \mathrm{O}_{5}\left(21.8 \mathrm{~kg} \mathrm{ha}^{-1}\right)$ and low in $\mathrm{K}_{2} \mathrm{O}(93.8 \mathrm{~kg}$ $\left.\mathrm{ha}^{-1}\right)$ at $0-15 \mathrm{~cm}$ soil depth. The soil was neutral in reaction (pH-7.1) with normal electric conductivity $\left(0.33 \mathrm{ds} \mathrm{m}^{-1}\right)$. The experiment was laid out in split-split plot design having three replications with date of planting of palmarosa in main plots, nitrogen levels in sub-plots and planting geometries in sub-sub plots. It consists of three planting dates of palmarosa plot viz. April 25, May 10 \&May 25, three nitrogen levels $(50,100 \&$ $\left.150 \mathrm{~kg} \mathrm{ha}^{-1}\right)$ in sub-plots and three planting geometries $(60 \mathrm{~cm} \times 30 \mathrm{~cm}, 60 \mathrm{~cm} \times 45 \mathrm{~cm} \& 60$ 
$\mathrm{cm} \times 60 \mathrm{~cm}$ ) in sub-sub plots during during two year crop cycles.

The palmarosa cultivar 'Kelkar' was propagated through $2.5 \mathrm{~kg}$ seed by raising seedling in nursery to transplant one hectare of main field. Raised nursery beds of $5 \times 1 \mathrm{~m}$ were prepared with $50 \mathrm{~cm}$ height. Farm yard manure was added in seed bed. As seeds were very small and light in weight, they were mixed with fine soil for even distribution. Lines of $3 \mathrm{~cm}$ deep and $10 \mathrm{~cm}$ apart were made and the seeds were uniformly sown in lines and covered with soil. The beds were irrigated with rose can on alternate days. The seeds got germinated within 3-4 days and 30 days old seedlings were ready for transplanting in the main field.

The field was thoroughly ploughed and levelled. Established seedlings were transplanted in the main field according to the date of planting, fertilized as per treatments of respective level of nitrogen with different planting geometry treatments. The palmarosa crop was fertilized with $50 \mathrm{~kg} \mathrm{P}_{2} \mathrm{O}_{5} \mathrm{ha}^{-1}$ and $40 \mathrm{~kg} \mathrm{~K} \mathrm{ha}{ }^{-1}$ (Gosh and Chatterjee, 1976) through single super phosphate and muriate of potash, respectively. Nitrogen was applied in the form of urea in four equal splits one as basal and the rest after three harvests during each year. The whole quantity of phosphorous and potassium were applied prior to transplanting. The crop was irrigated immediately after plantation for better establishment of the crop, subsequently once in a week and thereafter as and when required. Irrigation should be discontinued 7-10 days before harvesting. Hand weeding was done as weeds affect the yield and quality of the oil. The crop is kept weed free by periodical weeding for 1-2 months during early establishment period. After each harvest, a hoeing was done followed by irrigation. Three harvests were taken in each year after 120 days interval. The crop was manually harvested at full flowering stage with sickle leaving $15 \mathrm{~cm}$ stubble from ground level, which grew and yielded subsequent harvests.

The data on plant height, number of tillers per clump and biomass yield above the ground level were recorded at the time of each harvest. The green phytomass was weighed and recorded as biomass yield. Essential oil concentration $(\%)$ in the plant was estimated by hydro-distillation method using Clevenger's apparatus. A sample of about $300 \mathrm{~g}$ of herb was harvested and hydro-distilled in a Clevenger's apparatus for 3 hours. Moisture in oil samples were removed by sodium sulphate anhydrous $2 \%$. The oil concentration in plants was expressed as percentage on a volume basis ( $\mathrm{ml}$ oil obtained from $100 \mathrm{~g}$ of biomass). The essential oil yield was computed by multiplying biomass yield with essential oil concentration (\%) and expressed in $\mathrm{kg} \mathrm{ha}^{-1}$ (Rao, 2001). The pooled data of the two year crop cycles 2013-15 and 2014-16 subjected were subjected to statistical analysis following analysis of variance (ANOVA) for the qualitative and quantitative characters (Cocharan and Cox, 1959) and presented harvest wise.

\section{Results and Discussion}

\section{Growth attributes}

Plant height of palmarosa was not significantly influenced by different date of planting, nitrogen level and planting geometries at each harvest during two year crop cycles (Table 1). Different planting geometries did not show significant effect on plant height of patchouli at harvest stage (Singh, 2008). While differences in plant height due to nitrogen levels were significant during the first and second harvest years. Maximum plant height was observed with 150 $\mathrm{kg} \mathrm{N} \mathrm{ha}^{-1}$ which was statistically at par with $100 \mathrm{~kg} \mathrm{~N} \mathrm{ha}{ }^{-1}$. Higher plant height with application of $100 \mathrm{~kg} \mathrm{~N}^{-1}$ year $^{-1}$ has also been reported in Palmarosa (Takankhar et al., 2008). 
Table.1 Plant height and number of tillers clump ${ }^{-1}$ of palmarosa (Cymbopogon martinii) as influenced by various date of planting, nitrogen application and planting geometries during the years 2013-15 and 2014-16 (pooled data of two year crop cycles)

\begin{tabular}{|c|c|c|c|c|c|c|c|c|c|c|c|c|}
\hline \multirow[t]{3}{*}{ Treatments } & \multicolumn{6}{|c|}{ Plant height (cm) } & \multicolumn{6}{|c|}{ No. of tillers clump ${ }^{-1}$} \\
\hline & \multicolumn{3}{|c|}{$1^{\text {st }}$ year } & \multicolumn{3}{|c|}{$2^{\text {nd }}$ year } & \multicolumn{3}{|c|}{$1^{\text {st }}$ year } & \multicolumn{3}{|c|}{$2^{\text {nd }}$ year } \\
\hline & $\begin{array}{c}1^{\text {st }} \\
\text { harvest }\end{array}$ & $\begin{array}{c}2^{\text {nd }} \\
\text { harvest }\end{array}$ & $\begin{array}{c}3^{\text {rd }} \\
\text { harvest }\end{array}$ & $\begin{array}{c}1^{\text {st }} \\
\text { harvest }\end{array}$ & $\begin{array}{c}2^{\text {nd }} \\
\text { harvest }\end{array}$ & $\begin{array}{c}3^{\text {rd }} \\
\text { harvest }\end{array}$ & $\begin{array}{c}1^{\text {st }} \\
\text { harvest }\end{array}$ & $\begin{array}{c}2^{\text {nd }} \\
\text { harvest }\end{array}$ & $\begin{array}{c}3^{\text {rd }} \\
\text { harvest }\end{array}$ & $\begin{array}{c}1^{\text {st }} \\
\text { harvest }\end{array}$ & $\begin{array}{c}2^{\text {nd }} \\
\text { harvest }\end{array}$ & $\begin{array}{c}3^{\text {rd }} \\
\text { harvest }\end{array}$ \\
\hline \multicolumn{13}{|l|}{ Planting date } \\
\hline April 25 & 141.47 & 144.75 & 145.17 & 147.92 & 145.30 & 147.19 & 50.69 & 65.12 & 69.91 & 73.78 & 74.98 & 76.21 \\
\hline May 10 & 136.75 & 139.80 & 142.73 & 145.27 & 143.39 & 142.42 & 47.07 & 58.13 & 60.58 & 63.83 & 64.10 & 64.66 \\
\hline May 25 & 134.47 & 137.87 & 141.59 & 143.56 & 140.21 & 140.74 & 45.84 & 53.27 & 53.37 & 58.53 & 56.95 & 57.45 \\
\hline CD at $5 \%$ & NS & NS & NS & NS & NS & NS & 2.59 & 5.82 & 8.97 & 9.20 & 8.45 & 9.99 \\
\hline SEm \pm & 3.13 & 3.63 & 4.13 & 3.71 & 3.28 & 3.44 & 0.66 & 1.49 & 2.30 & 2.36 & 2.16 & 2.56 \\
\hline \multicolumn{13}{|l|}{ Nitrogen level } \\
\hline $50 \mathrm{~kg} \mathrm{ha}^{-1}$ & 129.40 & 131.42 & 136.21 & 138.92 & 136.43 & 134.49 & 42.51 & 49.14 & 54.48 & 57.62 & 55.94 & 57.06 \\
\hline $100 \mathrm{~kg} \mathrm{ha}^{-1}$ & 139.66 & 144.23 & 145.56 & 148.11 & 145.55 & 147.04 & 49.22 & 61.63 & 63.23 & 66.98 & 67.11 & 67.68 \\
\hline $150 \mathrm{~kg} \mathrm{ha}^{-1}$ & 143.63 & 146.78 & 147.71 & 149.72 & 146.92 & 148.84 & 51.85 & 65.75 & 66.16 & 71.54 & 72.97 & 73.57 \\
\hline CD at $5 \%$ & 8.28 & 7.96 & 7.64 & 8.15 & 8.28 & 8.45 & 5.83 & 10.13 & 6.69 & 8.26 & 9.16 & 8.46 \\
\hline SEm \pm & 2.69 & 2.58 & 2.48 & 2.65 & 2.69 & 2.74 & 1.89 & 3.29 & 2.17 & 2.68 & 2.97 & 2.75 \\
\hline \multicolumn{13}{|c|}{ Planting geometry } \\
\hline $60 \mathrm{~cm} \times 30 \mathrm{~cm}$ & 133.99 & 140.40 & 144.21 & 147.38 & 145.61 & 143.34 & 40.24 & 51.21 & 54.50 & 57.76 & 56.56 & 57.52 \\
\hline $60 \mathrm{~cm} \times 45 \mathrm{~cm}$ & 138.53 & 139.83 & 141.79 & 143.49 & 139.94 & 142.47 & 49.16 & 60.54 & 62.85 & 67.15 & 66.84 & 67.85 \\
\hline $60 \mathrm{~cm} \times 60 \mathrm{~cm}$ & 140.16 & 142.20 & 143.49 & 145.87 & 143.35 & 144.55 & 54.19 & 64.77 & 66.51 & 71.23 & 72.62 & 72.95 \\
\hline CD at $5 \%$ & NS & NS & NS & NS & NS & NS & 7.06 & 7.67 & 6.60 & 6.40 & 8.44 & 9.07 \\
\hline SEm \pm & 4.66 & 1.86 & 3.27 & 3.50 & 3.12 & 1.83 & 2.46 & 2.68 & 2.30 & 2.23 & 2.94 & 3.16 \\
\hline
\end{tabular}


Table.2 Influence of date of planting, nitrogen application and planting geometries on biomass yield of palmarosa (Cymbopogon martinii) during the years 2013-15 and 2014-16 (pooled data of two years)

\begin{tabular}{|c|c|c|c|c|c|c|}
\hline \multirow[t]{3}{*}{ Treatments } & \multicolumn{6}{|c|}{ Biomass yield $\left(\mathrm{t} \mathrm{ha}^{-1}\right)$} \\
\hline & \multicolumn{3}{|c|}{$1^{\text {st }}$ Year } & \multicolumn{3}{|c|}{$2^{\text {nd }}$ Year } \\
\hline & $\mathbf{1}^{\text {st }}$ harvest & $2^{\text {nd }}$ harvest & $3^{\text {rd }}$ harvest & $1^{\text {st }}$ harvest & $2^{\text {nd }}$ harvest & $3^{\text {rd }}$ harvest \\
\hline \multicolumn{7}{|l|}{ Planting date } \\
\hline April 25 & 6.01 & 7.63 & 9.20 & 9.95 & 10.50 & 10.60 \\
\hline May 10 & 4.34 & 5.82 & 7.31 & 8.26 & 8.70 & 8.68 \\
\hline May 25 & 3.89 & 4.78 & 6.54 & 6.95 & 7.64 & 7.72 \\
\hline CD at $5 \%$ & 1.34 & 1.45 & 1.55 & 1.41 & 1.40 & 1.73 \\
\hline SEm \pm & 0.34 & 0.37 & 0.40 & 0.36 & 0.36 & 0.44 \\
\hline \multicolumn{7}{|l|}{ Nitrogen level } \\
\hline $50 \mathrm{~kg} \mathrm{ha}^{-1}$ & 3.36 & 4.21 & 5.84 & 5.99 & 6.84 & 7.02 \\
\hline $100 \mathrm{~kg} \mathrm{ha}^{-1}$ & 5.07 & 6.69 & 8.20 & 8.80 & 9.67 & 9.67 \\
\hline $150 \mathrm{~kg} \mathrm{ha}^{-1}$ & 5.80 & 7.33 & 9.01 & 10.36 & 10.34 & 10.31 \\
\hline CD at $5 \%$ & 1.26 & 1.22 & 1.37 & 2.21 & 1.58 & 1.14 \\
\hline SEm \pm & 0.41 & 0.40 & 0.44 & 0.72 & 0.51 & 0.37 \\
\hline \multicolumn{7}{|c|}{ Planting geometry } \\
\hline $60 \mathrm{~cm} \times 30 \mathrm{~cm}$ & 5.99 & 7.61 & 8.54 & 9.87 & 10.74 & 10.57 \\
\hline $60 \mathrm{~cm} \times 45 \mathrm{~cm}$ & 4.30 & 5.83 & 7.45 & 7.94 & 8.66 & 8.81 \\
\hline $60 \mathrm{~cm} \times 60 \mathrm{~cm}$ & 3.94 & 4.79 & 7.06 & 7.32 & 7.44 & 7.62 \\
\hline CD at $5 \%$ & 1.48 & 1.62 & 0.88 & 1.76 & 1.54 & 1.60 \\
\hline SEm \pm & 0.52 & 0.56 & 0.31 & 0.61 & 0.54 & 0.59 \\
\hline
\end{tabular}


Table.3 Influence of date of planting, nitrogen application and planting geometries on oil content (\%) and essential oil yield ( $\left.\mathrm{kg} \mathrm{ha}^{-1}\right)$ of palmarosa (Cymbopogon martinii) during the years 2013-15 and 2014-16 (pooled data of two years)

\begin{tabular}{|c|c|c|c|c|c|c|c|c|c|c|c|c|}
\hline \multirow[t]{3}{*}{ Treatments } & \multicolumn{6}{|c|}{ Essential oil content (\%) } & \multicolumn{6}{|c|}{ Essential oil yield $\left(\mathrm{kg} \mathrm{ha}^{-1}\right)$} \\
\hline & \multicolumn{3}{|c|}{$1^{\text {st }}$ year } & \multicolumn{3}{|c|}{$2^{\text {nd }}$ year } & \multicolumn{3}{|c|}{$1^{\text {st }}$ year } & \multicolumn{3}{|c|}{$2^{\text {nd }}$ year } \\
\hline & $\begin{array}{c}1^{\text {st }} \\
\text { harvest }\end{array}$ & $\begin{array}{c}2^{\text {nd }} \\
\text { harvest }\end{array}$ & $\begin{array}{c}3^{\text {rd }} \\
\text { harvest }\end{array}$ & $\begin{array}{c}1^{\text {st }} \\
\text { harvest }\end{array}$ & $\begin{array}{c}2^{\text {nd }} \\
\text { harvest }\end{array}$ & $\begin{array}{c}3^{\text {rd }} \\
\text { harvest }\end{array}$ & $\begin{array}{c}1^{\text {st }} \\
\text { harvest }\end{array}$ & $\begin{array}{c}2^{\text {nd }} \\
\text { harvest }\end{array}$ & $\begin{array}{c}3^{\text {rd }} \\
\text { harvest }\end{array}$ & $\begin{array}{c}1^{\text {st }} \\
\text { harvest }\end{array}$ & $\begin{array}{c}2^{\text {nd }} \\
\text { harvest }\end{array}$ & $\begin{array}{c}3^{\text {rd }} \\
\text { harvest }\end{array}$ \\
\hline \multicolumn{13}{|l|}{ Planting date } \\
\hline April 25 & 0.59 & 0.61 & 0.65 & 0.65 & 0.67 & 0.67 & 34.36 & 46.12 & 59.84 & 64.93 & 70.40 & 71.70 \\
\hline May 10 & 0.57 & 0.60 & 0.65 & 0.64 & 0.66 & 0.66 & 24.72 & 34.90 & 47.32 & 53.48 & 57.48 & 57.75 \\
\hline May 25 & 0.58 & 0.59 & 0.63 & 0.64 & 0.65 & 0.67 & 21.84 & 29.38 & 41.38 & 44.36 & 49.94 & 51.76 \\
\hline CD at $5 \%$ & NS & NS & NS & NS & NS & NS & 8.26 & 9.57 & 8.07 & 8.50 & 9.78 & 11.59 \\
\hline SEm \pm & 0.01 & 0.02 & 0.02 & 0.01 & 0.01 & 0.01 & 2.12 & 2.45 & 2.07 & 2.18 & 2.51 & 2.97 \\
\hline \multicolumn{13}{|l|}{ Nitrogen level } \\
\hline $50 \mathrm{~kg} \mathrm{ha}^{-1}$ & 0.58 & 0.59 & 0.63 & 0.63 & 0.66 & 0.66 & 18.73 & 24.74 & 36.33 & 37.57 & 44.94 & 46.27 \\
\hline $100 \mathrm{~kg} \mathrm{ha}^{-1}$ & 0.57 & 0.60 & 0.65 & 0.65 & 0.66 & 0.67 & 28.88 & 40.47 & 53.25 & 57.33 & 64.03 & 64.87 \\
\hline $150 \mathrm{~kg} \mathrm{ha}^{-1}$ & 0.58 & 0.60 & 0.65 & 0.65 & 0.66 & 0.68 & 33.31 & 45.20 & 58.96 & 67.87 & 68.86 & 70.07 \\
\hline CD at $5 \%$ & NS & NS & NS & NS & NS & NS & 7.64 & 7.74 & 10.09 & 12.99 & 10.45 & 7.80 \\
\hline SEm \pm & 0.01 & 0.02 & 0.02 & 0.01 & 0.01 & 0.01 & 2.48 & 2.51 & 3.28 & 4.22 & 3.39 & 2.53 \\
\hline \multicolumn{13}{|c|}{ Planting geometry } \\
\hline $60 \mathrm{~cm} \times 30 \mathrm{~cm}$ & 0.58 & 0.60 & 0.65 & 0.64 & 0.66 & 0.68 & 34.78 & 47.07 & 55.92 & 63.09 & 71.03 & 71.45 \\
\hline $60 \mathrm{~cm} \times 45 \mathrm{~cm}$ & 0.58 & 0.60 & 0.64 & 0.65 & 0.66 & 0.67 & 24.16 & 34.98 & 47.62 & 52.52 & 57.44 & 58.92 \\
\hline $60 \mathrm{~cm} \times 60 \mathrm{~cm}$ & 0.57 & 0.59 & 0.64 & 0.64 & 0.66 & 0.66 & 21.98 & 28.36 & 44.99 & 47.16 & 49.36 & 50.85 \\
\hline CD at $5 \%$ & NS & NS & NS & NS & NS & NS & 8.66 & 10.08 & 5.73 & 11.91 & 10.59 & 10.38 \\
\hline SEm \pm & 0.01 & 0.02 & 0.01 & 0.01 & 0.01 & 0.01 & 3.02 & 3.51 & 2.00 & 4.15 & 3.69 & 3.62 \\
\hline
\end{tabular}


However, the differences in number of tillers clump $^{-1}$ of palmarosa due to different date of planting, nitrogen levels and planting geometries were influenced significantly at each harvest during two year crop cycles (Table 1). The maximum number of tillers clump $^{-1}$ was observed at April 25, which was significantly higher than that of May 10 and May 25. The highest number of tillers clump $^{-1}$ was obtained with $150 \mathrm{~kg} \mathrm{~N} \mathrm{ha}^{-1}$. Virtually there was no difference in number of tillers clump ${ }^{-1}$ in the crop raised with $100 \mathrm{~kg} \mathrm{~N}$ $\mathrm{ha}^{-1}$ and $150 \mathrm{~kg} \mathrm{~N} \mathrm{ha}^{-1}$. Also, Takankhar et al., 24 investigated that application of $100 \mathrm{~kg} \mathrm{~N}$ $\mathrm{ha}^{-1}$ year $^{-1}$ produced significantly higher number of tillers per plant of palmarosa. Among planting geometries, the maximum number of tillers clump ${ }^{-1}$ was produced by planting geometries of $60 \mathrm{~cm} \times 60 \mathrm{~cm}$ in each harvest, which was statistically at par with 60 $\mathrm{cm} \times 45 \mathrm{~cm}$ and both of these treatments proved significantly superior to $60 \mathrm{~cm} \times 30 \mathrm{~cm}$ planting geometry. The lowest number of tillers clump ${ }^{-1}$ was observed in $60 \mathrm{~cm} \times 30 \mathrm{~cm}$, which may be attributed to the fact that there was more number of plants under this treatment. Planting geometry with more space produced significantly more number of tillers than that of all the other planting geometries in palmarosa (Maheshwari et al., 1991).

\section{Biomass yield, oil content and essential oil yield}

Significant variations in date of planting, nitrogen levels and planting geometries were recorded with respect to biomass yield (Table 2) and essential oil yield (Table 3) at each harvest during two year crop cycles. Significantly the highest biomass yield and essential oil yield were recorded in April 25 which was significantly higher than May 10 and May 25 at each harvest during two year crop cycles. Significantly higher yields of herb and essential oil were noticed in different dates of planting of cymbopogan (Singh et al.,
2000). The yield differences in biomass yield of palmarosa (Table 2) and essential oil yield (Table 3) between levels of nitrogen were significant during both the harvest years. The highest biomass yield and essential oil yield were attained with $150 \mathrm{~kg} \mathrm{~N} \mathrm{ha}^{-1}$, which was statistically at par with $100 \mathrm{~kg} \mathrm{~N} \mathrm{ha}^{-1}$. The lowest biomass yield was obtained with $50 \mathrm{~kg}$ $\mathrm{N} \mathrm{ha}^{-1}$. Shrama et al., 1980 and Yadav et al., 1984 observed that there was significantly linear response to Nitrogen upto $150 \mathrm{~kg} \mathrm{~N} \mathrm{ha}^{-1}$ and found that the application of $150 \mathrm{~kg} \mathrm{ha}^{-1}$ resulted in high total biomass and essential oil yield in palmarosa. While, Khode et al., (1999) concluded that the $100 \mathrm{~kg} \mathrm{~N}^{-1}$ has significantly increased biomass and oil yield of palmarosa than lower $\mathrm{N}$ rates. The maximum biomass yield can be attributed to the favourable influence of nitrogen on plant height, tiller production which favours biomass yield of palmarosa (Singh and Sharma, 2001; Takankhar et al., 2008).

Among different planting geometries, the highest pooled biomass yield (Table 2) and essential oil yield (Table 3) of two year crop cycles were observed in planting geometries $60 \mathrm{~cm} \times 30 \mathrm{~cm}$, which was significantly superior to $60 \mathrm{~cm} \times 45 \mathrm{~cm}$ and $60 \mathrm{~cm} \times 60 \mathrm{~cm}$. This was due to the reason that the number of plants in $60 \mathrm{~cm} \times 30 \mathrm{~cm}$ was more than other spacing treatments. Maximum oil yield of palmarosa was obtained at $60 \mathrm{~cm} \times 30 \mathrm{~cm}$ spacing (Khode et al., 1999). Some other studies emphasized closer spacings for obtaining higher yields of aromatic crops in Assam, Bangalore, Hyderabad, Delhi, Kerala and Punjab (Singh et al., 2000). Rao et al., 1990 also obtained higher biomass yield and essential oil yield with closer spacing than wider spacing due to more number of plants per unit area.

The date of planting, land configuration and planting geometries resulted in non-significant values of oil content of palmarosa at both 
harvests during both the year of crop cycle (Table 3). The planting date did not influence oil content (Singh et al., 1991). Neither plant spacing nor nitrogen rate had any effect on the essential oil concentration in palmarosa (Rao et al., 1990)

Based on pooled data on two year crop cycle, it may be concluded that the highest biomass yield and essential oil yield were recorded in April 25 which obtained higher biomass yield and essential oil yield than May 10 and May 25 at each harvest during both the years of crop cycles. Also, higher biomass yield and essential oil yield were recorded in crop raised with $150 \mathrm{~kg} \mathrm{~N} \mathrm{ha}^{-1}$ which was statistically at par with $100 \mathrm{~kg} \mathrm{~N} \mathrm{ha}^{-1}$ during each harvest of palmarosa. Among planting geometries, the highest biomass yield and essential oil yield were observed in planting geometries $60 \mathrm{~cm} \times 30 \mathrm{~cm}$, which were significantly superior to $60 \mathrm{~cm} \times 60 \mathrm{~cm}$ and $60 \mathrm{~cm} \times 45 \mathrm{~cm}$. Further, date of planting, nitrogen application and planting geometries did not cause significant variation in the oil concentration.

\section{Acknowledgement}

Authors are grateful to Punjab State Council for Science and Technology, Chandigarh for encouragement and the support through DBT, New Delhi.

\section{References}

Akhila, A. 2009. Essential Oil-bearing Grasses: The Genus Cymbopogon (Medicinal and Aromatic Plants - Industrial Profiles). 1st ed. United States, Florida, Boca Raton: CRC Press.

Bard, M., Albrecht, M.R., Gupta, N., Guynn, C.J., and Stiliwell, W. 1988. Geraniol interferes with membrane functions in strains of Candida and Saccharomyces. Lipids. 23:53438.

Cochran, W. and Cox, G.M. 1959. Experimental designs. Asia Publishing House, New Delhi. India.
Das, M.K. and Ansari, M.A. 2003. Evaluation of repellent action of Cymbopogan martinii martinii Stapf var sofia oil against Anopheles sundaicus in tribal villages of Car Nicobar Island, Andaman \& Nicobar Islands, India. Journal of Vector Borne Diseases. 40 (3\&4):100.

Fatima, S., Farooqi, A.H. and Sharma, S. 2002. Physiological and metabolic responses of different genotypes of Cymbopogon martinii and $C$. winterianus to water stress. Journal of Plant Growth Regulation. 37:143-149.

Ghosh, M. L. and Chatterjee, S.K.1976. Effect of $\mathrm{N}, \mathrm{P}$ and $\mathrm{K}$ on growth and essential oil content of two species of cymbopogon. Scientific Culture. 42 (1): 490.

Gingade, S.R., Varghese, T.S. and Manivel, P. 2014. Cultivation of palmarosa. Extension Bulletin ICAR-Directorate of Medicinal and Aromatic Plants Research, Boriavi, Anand, Gujarat, p 1-20.

Khazaie, H.R., Nadjafi, F. and Bannayan, M. 2007. Effect of irrigation frequency and planting density on herbage biomass and oil production of thyme (Thymus vulgaris) and hyssop (Hyssopus officinalis). Industrial Crops and Products. 27(3): 315-321.

Khode, P. P., Ghatol, P. U., Dhumaiv, M. and Mahakal, N. N. 1999. Effect of spacing and nitrogen levels on foliage and oil yield of Palmarosa grass (Cymbopogon martinii). Agricultural Science Digest. 19 (4): 264-266.

Lodhia, M.H., Bhatti, K.R. and Thaker, V.S. 2009. Antibacterial activity of essential oils from palmarosa, evening primrose, lavender and tuberose. Indian Journal pharmaceutical Science 71: 134-136.

Maheshwari, S. K., Gangrade, S. K. and Chuhan, S. 1991. Influence of planting geometry on irrigated palmarosa oil grass. Indian Perfumer. 33: 177-180.

Mallavarapu, G.R., Rao, B.R.R., Kaul, Ramesh, S. and Bhattacharya, A.K. 1998. Volatile constituents of the essential oils of the seeds and the herb of palmarosa (Cymbopogon martinii (Roxb.) Wats. var. motia Burk.). Flavour Fragrance Journal. 13: 167-169.

Marotti, M., Piccaglia, R., Giovanelli, E., Deans, S.G. and Eaglesham, E. 1994. Effect of planting time and mineral fertilization on pepper mint (Mentha piperiata L.) essential 
oil composition and its biological activity. Flavor and Fragrance Journal. 9: 125-129.

Rao, B.R.R., Rajput, D.K. and Patel, R.P. 2009. Essential oil profiles of different parts of palmarosa (Cymbopogon martinii (Roxb.) Wats. var. motia Burk.). Journal of Essential Oil Research. 21: 519-521.

Rao, B.R.R. 2001. Biomass and essential oil yields of rainfed palmarosa (Cymbopogon martinii (Roxb.) Wats. var. motia Burk.) supplied with different levels of organic manure and fertilizer nitrogen in semi-arid tropical climate. Industrial Crops and Products. 14: 171-78.

Rao, B.R.R., Kaul, P.N., Syamasundar, K.V. and Ramesh, S. 2005.Chemical profiles of primary and secondary essential oils of palmarosa (Cymbopogon martinii (Roxb.) Wats var. motiaBurk.). Industrial Crops and Products. 21:121-27.

Rao, E. V. S.P., Singh, M., Rao, R.S.G. and Rao, B.R.R. 1990. Response of palmarosa (Cymbopogon martinii (Roxb). Wats. var. motia Burk.) to plant spacings and nitrogen fertilizer application. International Journal of Tropical Agriculture. 8(3): 177-183.

Sarma, J. S., Saini, S. S. and Bains, D. S.1977. Influence of row spacing $\mathrm{N}$ and $\mathrm{P}$ application of fresh herb and oil yield of Palmarosa (Cymbopogon mantinii Var. Motia). Indian Perfumer. 21(1): 44-46.

Sharma, S. N., Singh, A. and Tripathi, R. S. 1980. Response of palmarosa to nitrogen, phosphorus, potassium and zinc. Indian Journal of Agronomy. 25(4): 719-723.
Singh, K., Kothari, S. K., Singh, D. V., Singh, V. P. and Singh, P. P. 2000. Agronomic studies in cymbopogons- a review Journal of Spices and Aromatic Crops. 9(1): 13-22.

Singh, M. 2008. Influence of spacing and intercropping on biomass and essential oil yield of patchouli [Pogostemon cablin (Blanco) Benth.]. Journal of Spices and Aromatic Crops. 17(3): 235-239.

Singh, M. and Sharma, S. 2001. Influence of irrigation and nitrogen on herbage and oil yield of palmarosa (Cymbopogon martinii) under semi-arid tropical conditions. European Journal of Agronomy. 14: 157-159.

Singh, V. P., Kothari, S. K., Duhan, S. P. S. and Singh, D. V. 1991. Response of citronella (Cymbopogon winterianus Jowitt) to date of planting and frequency of harvest in subtropical India. International Journal of Tropical Agriculture. 9: 71-77.

Takankhar, V. G. 2008. Irrigation and Nitrogen Management in Palmarosa. Ph.D. thesis submitted to N.A.U., Navsari, Gujarat.

Yadav, R.L., Anwar, M. and Ram, M. 1984. Fertilizer nitrogen recovery and growth of Java Citronella as influenced by row spacing and nitrogen. Indian Journal Agronomy. 29(3): 305-308.

Zewdinesh, D.Z. and Beemnet, M.K. 2012. Agronomic characteristics and essential oil yield of Palmarosa (Cymbopogon martini (Roxb) as influenced by Population Density and Harvesting age at Wondo Genet, Southern Ethiopia. African Journal of Plant Science and Biotechnology 6(1): 73-75.

\section{How to cite this article:}

Sukhjit Kaur, Mandeep Kaur Saini and Deepinder Kaur Bakhshi. 2019. Influence of Date of Planting, Nitrogen Application and Planting Geometries on Growth, Biomass Yield and Essential Yield of Palmarosa (Cymbopogon martinii Roxb. Wats) under Sub-Mountainous Region of Punjab. Int.J.Curr.Microbiol.App.Sci. 8(11): 1310-1318. doi: https://doi.org/10.20546/ijcmas.2019.811.154 